\title{
A survey of bonobos and other large mammals in the Salonga National Park, Democratic Republic of Congo
}

\author{
Ellen Van Krunkelsven, Inogwabini Bila-Isia and Dirk Draulans
}

\begin{abstract}
In December 1997 and January 1998 we travelled to the northern section of the Salonga National Park in the Democratic Republic of Congo. The park is the largest African rain forest reserve, and was created in 1970 to protect endemic species such as the bonobo Pan paniscus and the Congo peacock Afropavo congensis. However, hardly any data exist on the status of animals in the park. In order to collect basic information, we set up camp at four sites along two rivers, where we followed long trails deep into the forest. A total of $7.5 \mathrm{~km}$ line transects were cut from three sites, along which all evidence of large mammals was recorded. Our data
\end{abstract}

\section{Introduction}

In 1956, King Leopold III of Belgium sailed on the Salonga River east from the village of Watsi Kengo, and decided to establish a large nature park in the area for the protection of the lowland rain forest (Schoonbroodt, 1987); the Salonga National Park was finally created in 1970. It is the largest rain forest reserve in Africa, and probably the world (IUCN, 1987; Doumenge, 1990). The United Nations Educational, Scientific and Cultural Organization (UNESCO) recognized the park in 1984 as a 'World Heritage Site' because of its huge size and the fact that it should protect rare endemic species such as the bonobo Pan paniscus and the Congo peacock Afropavo congensis (Mankoto, 1987).

Despite the park's conservation status, relatively little is known about the zoology of the area. Attempts to assess the number of forest elephants Loxodonta africana were seriously hampered by heavily-armed gangs of poachers (Alers et al., 1992). In fact, scientific research was impossible because of the activities of poachers who invaded the park shortly after its creation, and decimated the numbers of elephants and hippopot-

Ellen Van Krunkelsven Evolutionary Biology Group, Department of Biology, Groenenborgerlaan 171, B-2020 Wilrijk, Belgium. E-mail: vankrunk@ruca.ua.ac.be

Inogwabini Bila-Isia Wildlife Conservation Society, New York Zoological Society, Bronx, NY 10460, USA. E-mail: seba@kinpost. espmail.com

Dirk Draulans (corresponding author) Société Salonga, Museumlaan 61, B-3080 Tervuren, Belgium. E-mail: ddraulans@knack.be

Revised manuscript accepted for publication 6 March 2000 indicate that key forest species, including bonobo, bongo Tragelaphus euryceros, black mangabey Lophocebus atterimus and leopard Panthera pardus, are present in reasonable numbers in the part of the park we explored. Bonobo density was calculated at 1.15 animals per sq $\mathrm{km}$, based on nest counts. Some elephants Loxodonta africana survive, despite the enormous hunting pressure. Conservation measures to protect the animals need to be taken urgently.

Keywords Bonobos, Democratic Republic of Congo, mammals, Salonga National Park, threats.

amuses Hippopotamus amphibius (Bavela Vuadi, 1987; D'Huart, 1988; East, 1990). This situation still prevailed in 1996, when security problems prevented parrot researchers from sailing the Salonga (Fotso, 1996).

D'Huart (1988) stressed that the status, distribution and ecology of all species in the Salonga National Park were unknown; this is still the case today, with the exception of an account of the presence of seven monkey species and a few large predators along its northern border (Maisels et al., 1994a, b). In 1987, a group of bonobos was observed in the northern part of the park (Meder et al., 1988), which remained the only observation of the species by scientists until now. Thompson-Handler et al. (1995), who concluded that the world population of the bonobo could be as low as 5000 animals, pointed out that a large area of potential bonobo habitat, including the Salonga, has never been explored.

Here we present data from a survey of mammals in the Salonga National Park. We also report on the protection the park provides for the animals it houses.

\section{Methods}

The study area

The Salonga National Park covers an area of $36,560 \mathrm{sq} \mathrm{km}$, divided into a northern and a southern section of approximately equal size, separated by a zone of about $45 \mathrm{~km}$ (Fig. 1). It encompasses low plateaux covered by swamp forests, river terraces with an associated riverine forest and high plateaux with dry forest cover (IUCN, 1987). Rainfall is abundant, with an 
average of $2000 \mathrm{~mm}$ over the course of the year (Evrard, 1987). Evrard (1968) gives a full description of the vegetation in the region. Elephants are responsible for the presence of open marshes along some rivers.

Fieldwork was conducted during December 1997 and January 1998. We left from Mbandaka with a large dugout canoe equipped with an outboard motor. There is hardly any trade or transport left in the heart of the Congo, so we took all necessary food, fuel and camping gear with us. Our route took us along the Ruki and the Busira Rivers to reach the Salonga, the course of which we followed up to the village of Watsi Kengo, where

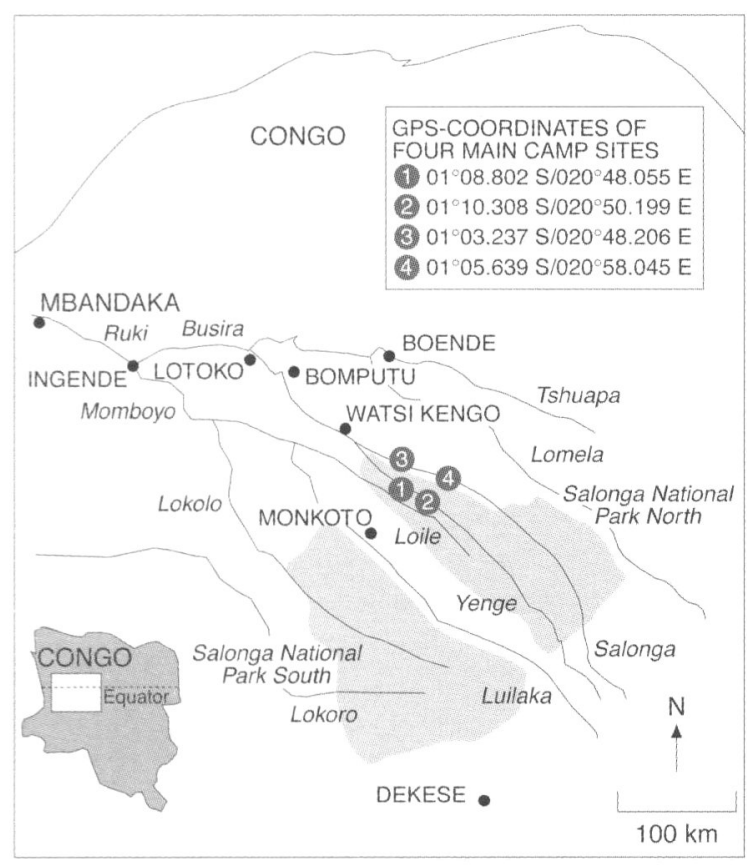

Fig. 1 Salonga National Park and the four main camp sites of the expedition. The white box in the Congo inset in the bottom left corner of the map shows the location of the full map in the country.

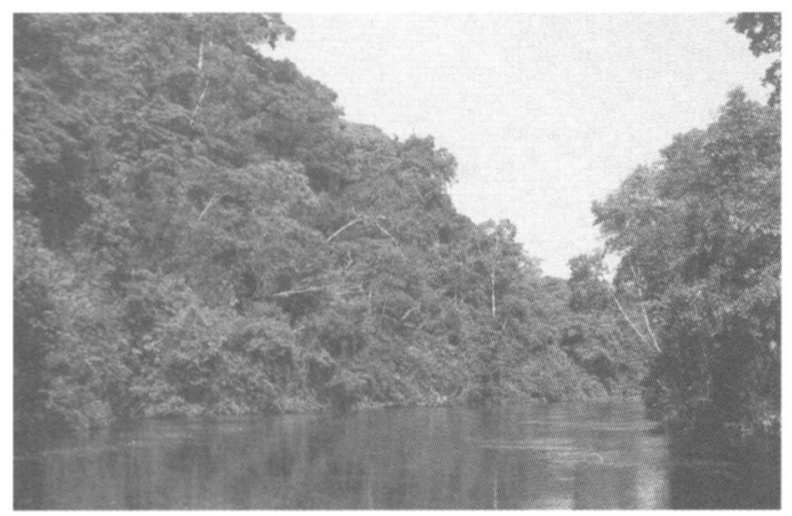

Plate 1 Vegetation along the Yenge River (Dirk Dramlans). we met conservator Albert Bofenda and his park guards, and hired local hunters as guides.

Our fieldwork focussed on the northern section of the park and followed first the course of the Yenge River for about $100 \mathrm{~km}$; we sampled the area intensively at two sites. In the second half of the trip we sampled two areas along the Salonga River. The initial plan was to sample three sites on each river, but problems with poachers prohibited this. In total, we sampled four sites (Fig. 1).

Apart from the Salonga being wider than the Yenge, and the banks of the Yenge occasionally being steep, both rivers and their riparian vegetation are similar (Plate 1). During our visit, the water level was very high and the rivers flowed fast. Throughout our stay, work was hampered by extremely heavy rainfall. This restricted greatly the sites at which we could enter the forest, and we were obliged to start our explorations from hunter camps in areas of old settlements, which were situated on the highest grounds close to the rivers.

\section{Field procedures}

We camped for 5 days at each of the four sites. On the first day we tried to follow a hunters' trail into the forest for a reconnaissance trip. However, because bonobos and other important animals could avoid these trails, we left the trails on the second day and entered the forest on compass bearings. The distances covered during the reconnaissance trips are presented in Table 1. The information recorded was used for qualitative assessments only of the animals present.

In order to collect quantitative information, we spent 3 days at each site cutting a straight-line transect of $2.5 \mathrm{~km}$ through the forest, perpendicular to the river, and pointing north-south (Fig. 2). At the second site, we had to abandon the cutting of a transect for security reasons. The transects of camps 1 and 3 were $19 \mathrm{~km}$ apart, and those of camps 3 and 4 were $30 \mathrm{~km}$ apart. Camp 2 was $18 \mathrm{~km}$ from camp 1 and $24 \mathrm{~km}$ from camp 4.

We tried to avoid starting the transects in riverine or inundated forest, because this could only be crossed in a canoe, which made the cutting of a transect almost impossible. Moreover, we wanted to sample mainly the dry forest because this is the most important habitat type in the park (Evrard, 1987). The transect was started at a random point out of the inundated forest, c. $1 \mathrm{~km}$ from the camp sites. On all days we used a nylon topofil to give an instantaneous recording of distance.

All evidence of large mammals was recorded, including direct observations, footprints, feeding remains, patches of dung, nests (for bonobos), sleeping sites on 


\begin{tabular}{|c|c|c|c|c|c|c|c|}
\hline & \multicolumn{2}{|c|}{ Yenge River } & \multicolumn{2}{|c|}{ Salonga River } & \multirow{2}{*}{$\frac{\text { Yenge River }}{\text { Transects }}$} & \multicolumn{2}{|c|}{ Salonga River } \\
\hline & \multicolumn{4}{|c|}{ Reconnaissance routes } & & \multirow[b]{2}{*}{ Camp 3} & \multirow[b]{2}{*}{ Camp 4} \\
\hline & Camp 1 & Camp 2 & Camp 3 & Camp 4 & Camp 1 & & \\
\hline Kilometres covered & 16.4 & 12.1 & 10.6 & 10.2 & 2.5 & 2.5 & 2.5 \\
\hline Feeding remains & 7 & 6 & 5 & 1 & 1 & 11 & 3 \\
\hline Footprints & 2 & 1 & 0 & 1 & 0 & 1 & 1 \\
\hline Number of nest groups & 0 & 0 & 4 & 0 & 0 & 6 & 2 \\
\hline Display sites & 2 & 0 & 0 & 0 & 0 & 0 & 0 \\
\hline Percentage of secondary forest & & & & & 46 & 20 & 94 \\
\hline Percentage of canopy cover & & & & & 69 & 69 & 49 \\
\hline \multicolumn{8}{|l|}{ Understorey: percentage cover } \\
\hline Trees & & & & & 26 & 44 & 2 \\
\hline Marantacea & & & & & 38 & 38 & 92 \\
\hline Lianas & & & & & 36 & 18 & 6 \\
\hline
\end{tabular}
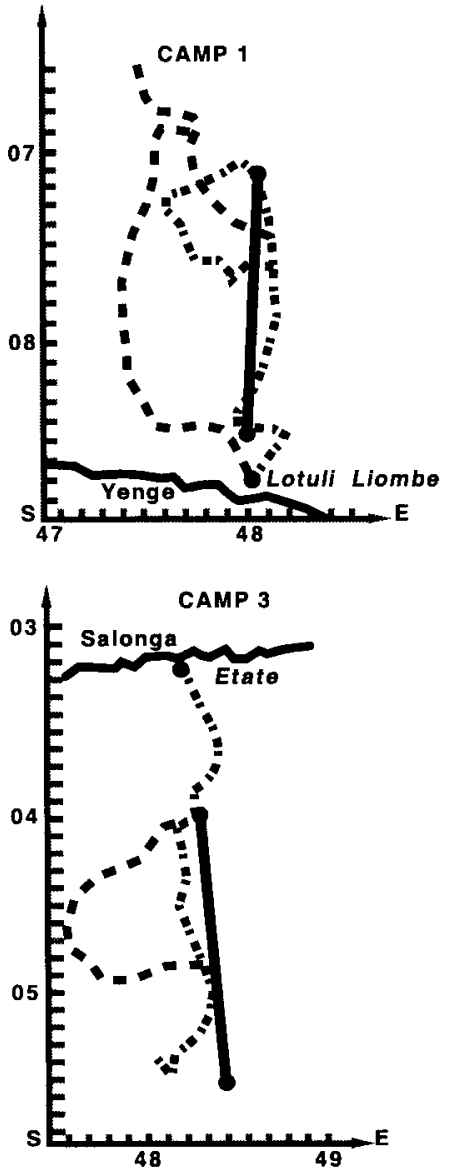
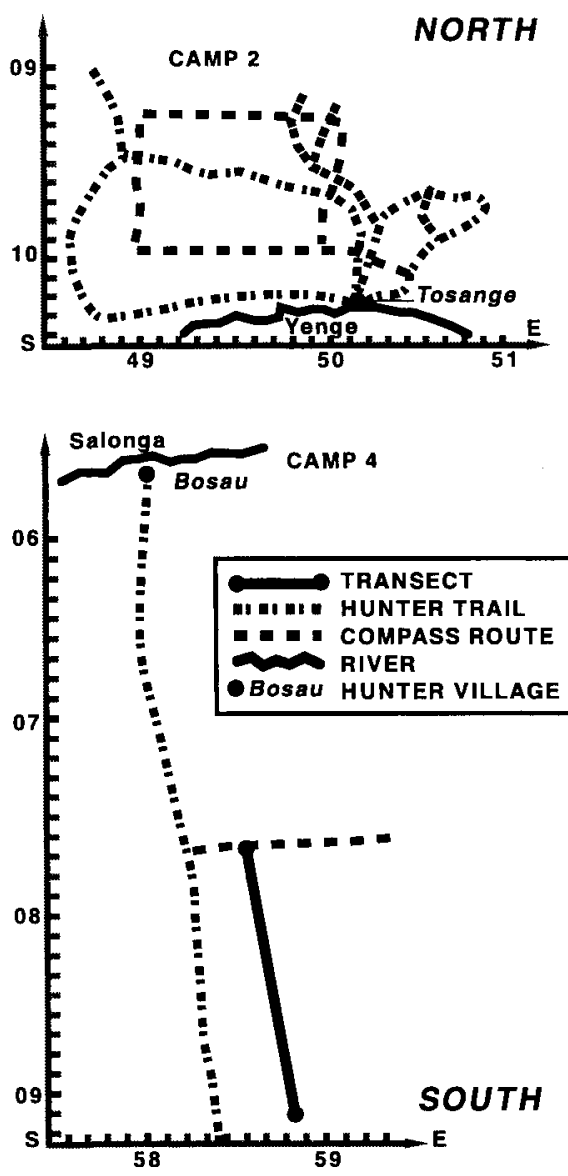

Table 1 List of bonobo evidence und at the different camp sites
Fig. 2 Reconnaissance routes (hunter trails and compass routes) and transects at the four main camp sites. Numbers along axes are degrees south (S) and east (E). the ground (for antelopes) and hunter camps. Where possible, we recorded Global Positioning System (GPS) locations of the important findings, such as nests of bonobos, dung of elephants and hunter camps. Along the transects we recorded the type of forest at $50-\mathrm{m}$ intervals as well as when we found evidence of animals. Specifically, mature or secondary forest, percentage of canopy cover by simple visual estimation, and 
type of understorey (domination by Marantacea species, lianas or small trees) were recorded. A full description of this habitat classification is given in Hall et al. (1998).

For every bonobo nest we observed from the transect line, we measured the distance to the transect with a 50-m measuring tape, and determined its characteristics according to Fruth \& Hohmann (1993). From this information we calculated the density of bonobos using the formulas of Tutin \& Fernandez (1983) and Ghiglieri (1984). Full details of the method are given in Van Krunkelsven et al. (in press).

\section{Results}

\section{Non-human primates}

We found evidence of the presence of bonobos at all four sample sites, but nests along the Salonga River only (Table 1). Food remains were mainly Haumania liebrechtsiana. Most footprints were discovered in small river beds. In the area of camp 1, we found two sites with small broken trees where bonobos had been displaying: the animals drag branches or small trees up and down the forest to impress others (branch dragging as defined by Kano, 1992).

We found eight groups of 38 bonobo nests in total along the transect lines, and four groups of 22 nests in total along the reconnaissance routes at camp 3: three groups of 20 nests in total along the hunters' trail and one group of two nests off the trail. The median group size of nests was five. All nest groups along the transects were found in mature forest with an average canopy cover of 62 per cent and an understorey dominated by Marantacea.

Within $25 \mathrm{~m}$ of the transect, we found 30 nests covering an area of $0.375 \mathrm{sq} \mathrm{m}$. The formulas of Tutin \& Fernandez (1983) and Ghiglieri (1984) gave the same result: a density of 1.15 bonobos per sq $\mathrm{km}$.

Apart from the bonobo and the nocturnal Demidoff's galago Galagoides demidovi, we recorded seven species of non-human primates (Table 2). We did not attempt to count individuals because the cutting of transects is not suitable for detailed monkey observations. Nevertheless, black mangabey Lophocebus atterimus, red-tailed guenon Cercopithecus ascanius and Wolf's guenon Cercopithecus mona wolfi were observed almost every day. They often formed mixed-species groups, especially in the area close to the Salonga River. Most females of the latter species had babies. Along the rivers we saw all species except Wolf's guenon. A group of De Brazza's monkeys Cercopithecus neglectus was observed swimming across the Yenge, undeterred by its rapid flow.

There was no indication of the presence of Salonga monkey Cercopithecus dryas, although the hunters we hired claimed there was yet another primate species living in the park, which they called 'eleki'. This is the local name cited by Colyn (1992) for the Salonga monkey, but our guides did not recognize the species from the picture provided by Kingdon (1997).

\section{Other mammals}

Table 3 summarizes our data for 12 other species of large mammals. Of note was the presence of bongo Tragelaphus euryceros, giant ground pangolin Smutsia gigantea and golden cat Felis aurata.

We found traces of elephants at three of the four sample sites, the greatest number of which were in the area where we could not cut a transect for security reasons. Along the trail in the same area we found tracks of a herd of elephants, including a baby. All other observations related to individual animals. Both of the elephant marshes we visited, one on each river, were largely overgrown by vegetation, including small trees with a trunk diameter breast size (DBS) of over $10 \mathrm{~cm}$, suggesting that the marshes are no longer used by elephants; this fact was confirmed by our guides. Two poachers arrested in the park confessed to having shot a small elephant in our second sample area 3 months before our visit. They sold the ivory in Mbandaka for about \$US 15. The poachers admitted that it has become increasingly difficult to find elephants in the forest.

Table 2 List of all monkey sightings along the rivers and at the trails of the different camp sites

\begin{tabular}{|c|c|c|c|c|c|}
\hline & Sightings along rivers & Camp 1 & Camp 2 & Camp 3 & Camp 4 \\
\hline Black and white colobus Colobus polykomos & $+t$ & 2 & 0 & 5 & 0 \\
\hline Tshuapa red colobus Piliocolobus tholloni & + & 0 & 0 & 0 & 1 \\
\hline Black mangabey Lophocebus atterimus & + & 1 & 1 & 0 & 2 \\
\hline Wolf's guenon Cercopithecus mona wolfi & - & 4 & 1 & 3 & 4 \\
\hline Red-tailed guenon Cercopithecus ascanius & + & 2 & 0 & 6 & 3 \\
\hline De Brazza's monkey Cercopithecus neglectus & ++ & 0 & 0 & 0 & 0 \\
\hline Allen's swamp monkey Allenopithecus nigroviridis & + & 1 & 0 & 0 & 0 \\
\hline
\end{tabular}

++ : daily sightings along rivers; + : regular, but not daily, sightings; - : no sightings along rivers. 
Table 3 Encounter rates of evidence (footprints or direct sightings) of all large mammals others than primates

\begin{tabular}{|c|c|c|c|c|c|c|c|}
\hline & \multicolumn{2}{|c|}{ Yenge River } & \multicolumn{2}{|c|}{ Salonga River } & \multirow{2}{*}{$\begin{array}{l}\text { Yenge River } \\
\text { Transects }\end{array}$} & \multicolumn{2}{|c|}{ Salonga River } \\
\hline & \multicolumn{4}{|c|}{ Reconnaissance routes } & & \multirow[b]{2}{*}{ Camp 3} & \multirow[b]{2}{*}{ Camp 4} \\
\hline & Camp 1 & Camp 2 & Camp 3 & Camp 4 & Camp 1 & & \\
\hline Kilometres covered & 16.4 & 12.1 & 10.6 & 10.2 & 2.5 & 2.5 & 2.5 \\
\hline Bongo Tragelaphus euryceros & 0 & 0 & 0 & 5 & 0 & 0 & 1 \\
\hline Sitatunga Tragelaphus spekii & 0 & 0 & 1 & 0 & 0 & 0 & 0 \\
\hline Black fronted duiker Cephalophus nigrifrons & 6 & 5 & 4 & 5 & 10 & 5 & 8 \\
\hline Bay duiker Cephalophus dorsalis & 1 & 2 & 1 & 0 & 3 & 2 & 2 \\
\hline Yellow-backed duiker Cephalophus sylvicultor & 2 & 4 & 3 & 9 & 1 & 2 & 7 \\
\hline Blue duiker Cephalophus monticola & 1 & 4 & 0 & 1 & 4 & 2 & 0 \\
\hline Water chevrotain Hyemoschus aquaticus & 1 & 0 & 1 & 1 & 3 & 0 & 0 \\
\hline Red river hog Potamochoerus porcus & 8 & 11 & 7 & 6 & 9 & 4 & 6 \\
\hline Giant ground pangolin Smutsia gigantea & 1 & 0 & 0 & 0 & 0 & 0 & 0 \\
\hline Leopard Panthera pardus & 2 & 0 & 0 & 2 & 0 & 0 & 0 \\
\hline Golden cat Felis aurata & 0 & 0 & 0 & 0 & 0 & 1 & 0 \\
\hline \multicolumn{8}{|l|}{ Forest elephant Loxodonta africana } \\
\hline Sites with dung & 1 & 5 & 0 & 0 & 1 & 1 & 1 \\
\hline Footprints & 0 & 11 & 0 & 1 & 1 & 0 & 1 \\
\hline Feeding remains & 0 & 8 & 0 & 0 & 0 & 0 & 0 \\
\hline
\end{tabular}

No traces of hippopotamus or forest buffalo Syncerus caffer nanus were found. We saw or heard lots of small mammals, including African brush-tailed porcupine Atherurus africanus and tree hyrax Dendrohyrax arboreus.

\section{Humans}

Along the Yenge River we recorded 22 temporary hunting camps and along the Salonga there were 21 such camps, which gives an average of about one camp every $5 \mathrm{~km}$. Some of these contained up to 10 huts. At each of the four study sites we found a hunter trail and huts deep inside the forest, sometimes accompanied by small fields and papaya or avocado trees. Most of these were used by local hunters from villages along the park borders. Some trees were carved up for the collection of copal.

The density of snares and traps was considerable, especially along the Salonga, which forms the border of the park in the area we visited: at site 3 we counted 82 traps on $4 \mathrm{~km}$ of trail. We also found empty cartridges of calibre-12. Our guides confirmed, reluctantly, that there is extensive hunting for meat in large areas of the park.

Each river had a gang of heavily-armed poachers. On the Yenge, our guards arrested two poachers with 136 bullets for automatic Fal-machineguns. One of them had been a soldier in the former Zairean army of Mobutu, and fled to the park with his arms after the fall of Kinshasa in June 1997. The gang used an outboard motor and at least 10 automatic weapons. Local people claimed it was commanded by an ex-colonel of Mobu- tu's army. In the camp we raided, we found huge amounts of dried fish and small crocodiles.

The Salonga River had a similar gang, operated by a criminal known as 'Lisala', who recruited local hunters.

\section{Discussion}

Our data indicate that bonobos are common in the part of the park we explored. This was confirmed by local hunters, who claimed that the animal, which they know by the name 'emana', is present throughout the park, but shies away from people. The first bonobo field researchers reported indirect information that no bonobos lived in the park (Badrian \& Badrian, 1977; Kano, 1979). However, Meder et al. (1988) observed three bonobos along its northern border, and found lots of traces of the animals. D'Huart (1988) confirmed the presence of bonobos, based on information provided by park guards.

A density of 1.15 bonobos per sq $\mathrm{km}$ is reasonable, compared with the minima of 0.43 and 0.45 (Uehara, 1988; Sabater-Pi \& Vea, 1990) and the maxima of 1.71 and 2.98 (Kano, 1992; Van Krunkelsven et al., in press) recorded elsewhere. However, because forest cover is not homogeneous across the park (Evrard, 1968), no generalization regarding the occurrence of the species can be made from our sample.

In the area studied, no taboo on hunting bonobos exists, unlike in the forests further north in the province, where people insist that the Salonga region is renowned for its inhabitants who consider bonobo meat to be a delicacy (Van Krunkelsven, unpublished infor- 
mation). The fact that we did not see or hear any bonobos could be attributed to the lack of fruit. Maisels et al. (1994a) reported that fruit availability along the northern border of the park was low in December and January. As far as chimpanzees are concerned, low availability of fruit correlates with a low number of encounters (Ghiglieri, 1984).

The part of the park we explored contains a high diversity of primate species in relatively large numbers. Important predators such as leopard and golden cat are present. We heard the Congo peacock at all four sites where we camped (Van Krunkelsven \& Draulans, 2000). Raptors and hornbills were abundant, indicating a largely intact ecosystem. The abundance and diversity of animals was striking considering the hunting pressure that has afflicted the park almost since its creation. Hunting has not yet eliminated many mammals from the forest, as has been the case elsewhere in the region (Van Krunkelsven, unpublished information).

Elephants survive in the park, be it in low numbers. In the 1970s, the region was densely populated by elephants, as witnessed by old hunters. Alers et al. (1992) mentioned that the area between the Yenge and the Salonga Rivers was particularly rich in elephants, probably because of the presence of large patches of secondary forest, which form a mosaic with primary forest that the elephant favours (Evrard, 1987; Barnes et al., 1991). Considering the fact that the forest elephant has disappeared from a large part of its range in Congo (Barnes et al., 1995), its survival in the park could be significant.

The question remains: how long will the species last? Fotso (1996) described an encounter at the mouth of the Salonga River with an armed gang who transported at least 20 large tusks to Mbandaka. Three weeks before our arrival, authorities shot three poachers-reportedly carrying tusks - on the Lomela River, north of the park.

The only protection the Salonga National Park offers its animals is the absence of logging threats. The hunt for bushmeat, however, is important. On the rivers to Mbandaka we encountered dugout canoes full of smoked duikers, bush pigs and monkeys, and living monkeys and tortoises. Bushmeat, including sitatunga Tragelaphus spekii, was abundant on the market of Mbandaka.

The presence of heavily-armed poachers prevents the park guards from doing their job. At the end of the 1980s, a number of guards were shot dead (A. Bofenda, pers. comm.). In the 7 years prior to our expedition no patrols took place on the rivers in the park. The park guards also lost their weapons during the turmoil in the former Zaire. For years they were not paid, as was the case elsewhere in the country (Hart \& Hall, 1996). It was significant that the (then new) military auth- orities gave the park guards automatic weapons to protect our expedition and resume patrolling in the park, mainly because they assumed that most poachers were soldiers from the former Zairean army.

The Salonga National Park is - at least on paperthe only protected area in the living range of the bonobo: all other forests in its range are logging concessions. It is also an extremely large and relatively undisturbed forest that could serve as a reservoir for what is being lost elsewhere. This strengthens the need for solid efforts to evict poachers and hunters from the park and start patrols again, which supposes providing park guards with the means to perform their duty (D'Huart, 1988). The river system of the park facilitates efficient patrolling because the rivers are almost the only access routes into the park.

Unfortunately, the Democratic Republic of Congo remains unstable: a second rebellion in the space of 3 years hit the country in the summer of 1998. In winter 1999 , all parks were within or close to rebel territory. There are worrying reports of the large-scale slaughter of wildlife, including elephants and gorillas Gorilla gorilla graueri, by groups of renegade fighters and refugees hiding in the Maiko and Kahuzi-Biega National Parks.

These parks already suffered heavily during the first rebellion in 1997 and the refugee crisis after the Rwandan genocide in 1994, as did the National Parks of Garamba and Virunga (Hart et al., 1996; Hart \& Hart, 1997). Based on preliminary lessons learned from the first rebellion, Hart \& Hart (1997) concluded that the best preparation for conservation in the face of regional instability was the professional development of national staff and strong site-based conservation programs'. As far as the Salonga National Park is concerned, even this challenge was never taken on, as the pressure from poachers prevented conservation efforts being pursued.

Our work shows that, with the right kind of precautions and the sensible motivation of local authorities, it is possible to work in the Salonga National Park. It also shows that most important animal species still live in the park, although pressure by bushmeat hunters is increasing rapidly. Conservation authorities need to be ready to move in and support the park guards as soon as the situation in the region is safe enough. A detailed programme for the management of the park is available (Van Krunkelsven, unpublished report).

\section{Acknowledgements}

We thank the Zoological Society of Milwaukee County, particularly Dr. Gay Reinartz, for funding the ex- 
pedition. The direction of the Institut Congolais pour la Conservation de la Nature (ICCN) in Kinshasa, and in particular Président Délégué Général Malembe Mbo, granted permission to visit the park. Philip Heuts, André Moens and Eric De Bock of the Belgian Embassy provided invaluable assistance, as did James and Betsy Williamson of the American Embassy and Delfi Messinger. In Mbandaka we received crucial support from vice-governor Edmond Mondombo Kanzo, and from Father Piet Hens and Sister Maria Pelckmans of the Mission de Sacre Coeur. Steve Weeks kindly allowed us to stay at his house. Tony Mombaers drew the maps.

\section{References}

Alers, M., Blom, A., Sikubwabo Kiyengo, C., Masunda, T. \& Barnes, R. (1992) Preliminary assessment of the status of the forest elephant in Zaire. African Journal of Ecology, 30, 279-291.

Badrian, A. \& Badrian, N. (1977) Pygmy chimpanzees. Oryx, 13, 463-468.

Barnes, R., Barnes, K., Alers, M. \& Blom, A. (1991) Man determines the distribution of elephants in the rain forests of northeastern Gabon. African Journal of Ecology, 29, 54-63.

Barnes, R., Blom, A. \& Alers, M. (1995) A review of the status of forest elephants Loxodonta africana in Central Africa. Biological Conservation, 71, 125-132.

Bavela Vuadi, R. (1987) Lutte anti-bracconage en dehors du Parc et son impact sur la surveillance. In Premier Séminaire International sur la Gestion et l'avenir du Parc National de la Salonga, pp. 89-94. Institut Zairois pour la Conservation de la Nature, Mbandaka.

Colyn, M. (1992) Cercopithecus dryas and Cercopithecus salonga are the same species. Folia Primatologica, 56, 167-170.

D'Huart, J.P. (1988) Parc National de la Salonga (Equateur, Zaire): Conservation et Gestion. IUCN, Gland.

Doumenge, C. (1990) La Conservation des Écosystèmes Forestiers du Zaire. IUCN, Gland.

East, R. (1990) Antelopes. Global Survey and Regional Action Plans. Part 3. West and Central Africa. IUCN, Gland.

Evrard, C. (1968) Recherche Écologique sur le Peuplement Forestier des Sols Hydromorphes de la Cuvette Centrale Congolaise. Série scientifique de l'Institut National des Etudes Agronomiques en Congo Belge, Brussels.

Evrard, C. (1987) Cadre biogéographique du Parc National de la Salonga. In Premier Séminaire International sur la Gestion et l'avenir du Parc National de la Salonga, pp. 43-48. Institut Zairois pour la Conservation de la Nature, Mbandaka.

Fotso, R. (1996) Examen du Status, Étude de la Distribution et de l'utilisation du Perroquet Gris (Psittacus erythacus) au Zaire. CITES, Lausanne.

Fruth, B. \& Hohmann, G. (1993) Ecological and behavioral aspects of nest building in wild bonobos (Pan paniscus). Ethology, 94, 113-126.

Ghiglieri, M. (1984) The Chimpanzees of Kibale Forest, a Field Study of Ecology and Social Structure. Columbia University Press, New York.
Hall, J., White, L., Bila-Isia, I., Ilambu, O., Morland, H., Williamson, E. et al. (1998) A survey of Grauer's gorillas (Gorilla gorilla graueri) and chimpanzees (Pan troglodytes schweinfurthii) in the Kahuzi-Biega National Park Lowland Sector and adjacent forests in eastern Democratic Republic of Congo. International Journal of Primatology, 19, 207-235.

Hart, J. \& Hall, J. (1996) Status of eastern Zaire's parks and reserves. Conservation Biology, 10, 316-327.

Hart, T. \& Hart, J. (1997) Conservation and civil strife: two perspectives from Central Africa. Conscrvation Biology, 11, 308-309.

Hart, T., Hart, J. \& Hall, J. (1996) Conservation in the declining nation state: a view from eastern Zaire. Conservation Biology, 10, 685-686.

IUCN (1987) Directory of Afrotropical Protected Areas. IUCN, Gland.

Kano, T. (1979) A pilot study of pygmy chimpanzees (Pan paniscus). In The Great Apes (eds D. Hamburg and E. McCown), pp. 122-135. Benjamin/Cummings, Palo Alto.

Kano, T. (1992) The Last Ape. Pygmy Chimpanzee Behavior and Ecology. Stanford University Press, Stanford.

Kingdon, J. (1997) The Kingdon Field Guide to African Mammals. Academic Press, London.

Maisels, F., Gautier-Hion, A. \& Gautier, J.P. (1994a) Diets of two sympatric colobines in Zaire: more evidence of seed-eating in forests on poor soils. International Journal of Primatology, 15, 681-701.

Maisels, F., Gautier, J.P., Cruickshank, A. \& Bosefe, J.P. (1994b) Attacks by crowned hawk eagles (Stephanoaetus coronatus) on monkeys in Zaire. Folia Primatologica, 61, 157-159.

Mankoto, M. (1987) Adresse du président délégué général de l'institut zairois pour la conservation de la nature. In Premier Séminaire International sur la Gestion et l'avenir du Parc National de la Salonga, pp. 9-12. Institut Zairois pour la Conservation de la Nature, Mbandaka.

Meder, A., Herman, P. \& Bresch, C. (1988) Pan paniscus in Salonga National Park. Primate Conservation, 9, 110-111.

Sabater-Pi, J. \& Vea, J. (1990) Nest building and population estimates of the bonobo from Lokofe-Lilungu-Ikomaloki region of Zaire. Primate Conservation, 11, 43-47.

Schoonbroodt, A. (1987) Motifs de la création et historique ancien du Parc National de la Salonga. In Premier Séminaire International sur la Gestion et l'avenir du Parc National de la Salonga, pp. 39-40. Institut Zairois pour la Conservation de la Nature, Mbandaka.

Thompson-Handler, N., Málenky, R. \& Reinartz, G. (1995) Action Plan for Pan paniscus: Report on Free Ranging Populations and Proposals for their Preservation. The Zoological Society of Milwaukee County, Milwaukee, WI.

Tutin, C. \& Fernandez, M. (1983) Récensement des Gorilles et des Chimpanzés du Gabon. University of Stirling, Stirling.

Uehara, S. (1988) Grouping patterns of wild pygmy chimpanzees (Pan paniscus) observed at a marsh grassland amidst the tropical rain forest of Yalosidi, Republic of Zaire. Primates, 29, 41-52.

Van Krunkelsven, E. \& Draulans, D. (2000) A first list of birds from Salonga National Park, Congo. Gerfaut 87.

Van Krunkelsven, E., Dupain, J., Van Elsacker, L. \& Verkeyen, R. (in press) Density estimation of bonobos (Pan paniscus) by nest counts at the Lomako Forest, Congo. Animal Conservation. 


\section{Biographical sketches}

Ellen Van Krunkelsven holds a degree in biology from the University of Antwerp, Belgium, and wrote a dissertation on vocal communication of bonobos in captivity. Since 1994 she has studied the social interactions of bonobos in the Lomako Forest of Congo/Zaire-work which had to be abandoned because of the turmoil in the country. In anticipation of an improvement in the situation she joined a project in which giant poached rats are trained to detect landmines.

Inogwabini Bila-Isia studied physics at the University of Kinshasa, Democratic Republic of Congo. He joined a longterm expedition of the Wildlife Conservation Society (WCS) to the Kahuzi-Biega National Park in his country, and received a grant from the WCS to study population dynamics at Cambridge University, UK. He currently lives in Kinshasa, dealing with issues of nature conservation.

Dirk Draulans has a PhD in biological sciences from the University of Leuven, Belgium, and spent 2 years as a postdoctoral researcher at Oxford University, UK. He joined several scientific expeditions to Africa. He is now a writer/journalist with a focus on the deteriorating situation in Africa, and has written two books on his African experiences. 